\title{
Investment Analysis for Submarine Power Cable Project Between Belakang Padang Island and Sambu Island
}

\author{
Agus Wibowo and Erman Sumirat
}

\section{ABSTRACT}

PT Pertamina (Persero) Riau Islands proposed the installation of electrical power for the fuel storage tank terminal on Sambu Island with a capacity of 7 MVA. Currently, Sambu Island is still receiving electricity by operating a Diesel Power Plant (PLTD) with diesel fuel.

Seeing that the nearest electricity supply from Sambu Island is Pulau Belakang Padang Electricity, then as a business solution to be able to meet the demand of PT Pertamina (Persero), PT PLN Batam will build a submarine cable between Sambu Island - Pulau Belakang Padang to distribute electricity from the Power Plant in Batam to Sambu Island through the Belakang Padang Island.

PT PLN Batam must obtain a reference regarding the feasibility of investing in the construction of a submarine cable between Belakang Padang-Sambu Island. To get this reference, an investment analysis must be carried out to determine the business feasibility of this submarine cable development.

The business feasibility parameters to be analyzed are NPV (Net Present Value), IRR (Internal Rate of Return), BCR (Benefit to Cost Ratio) and PBP (Payback Period). To further refine the business feasibility analysis, a sensitivity analysis was carried out to see the effect of changes in investment parameters.

\begin{abstract}
After conducting investment analysis, it was found that the Capital was carried out with a portion of $30 \%$ from equity and $70 \%$ loans from domestic financial institutions after comparing with foreign financial institutions, and the construction of this submarine cable was declared feasible because it met all the feasibility parameters. business, where NPV $>0, B C R>1$, IRR $>$ Discount Rate and PBP < Loan Tenor.

With the construction of the submarine cable, PT PLN Batam will get a potential profit of Rp. 12.358.560.473, - in the first year after the operation of the submarine cable with an electricity tariff of Rp. 2,054 /Kwh. This electricity tariff is cheaper than the electricity tariff using PLTD of Rp 3,000/Kwh.
\end{abstract}

Keywords: Feasibility Analysis, Risk Mitigation, Submarine Cable, Toll Fee Tariff.

Submitted : September 08, 2021

Published : October 06, 2021

ISSN: $2507-1076$

DOI: $10.24018 /$ ejbmr.2021.6.5.1098

Agus Wibowo*

School of Business and Management Institute Technology of Bandung, Indonesia.

(e-mail: agus_wibowo ${ }^{\circledR}$ sbm-itb.ac.id) Erman Sumirat

School of Business and Management Institute Technology of Bandung, Indonesia.

(e-mail: erman.sumirat@sbm-itb.ac.id)

*Corresponding Author

\section{INTRODUCTION}

PT. PLN Batam is an agency that holds a General Electricity Business License (PIUKU) with a working area of Batam, Rempang and Galang. In 2017, PT Pertamina (Persero) Riau Islands proposed the installation of electrical power for the fuel storage tank terminal on Sambu Island with a capacity of 7 MVA. Sambu Island is in the business area of PT PLN Persero Riau and Riau Islands Region (PLN WRKR). The closest electricity network to Sambu Island is Belakang Padang Island (PLN WRKR business area) and Sekupang - Batam (PLN Batam Business Area).

The electricity for Belakang Padang Island itself is supplied from Batam electricity through a $20 \mathrm{KV}$ Type $\mathrm{Cu}$ marine Cable with a size of $150 \mathrm{~mm}^{2}$ from GD KTM Resort Tanjung Pinggir - Sekupang. By looking at the nearest electricity supply, as a business solution to meet PT Pertamina's demand is to build a submarine cable between Sambu Island - Belakang Padang Island to distribute electricity to Sambu Island from Belakang Padang Island.

Currently, Sambu Island still gets electricity from the operation of a diesel-fueled diesel generator, where the operation of this diesel-fueled plant is very expensive in terms of operating and maintenance costs.

In Batam itself, many shipbuilding industries, factories and other types of businesses have suffered losses, reduced their production capacity and even closed their activities. This affects electricity sales by PT PLN Batam as the electricity provider in Batam. Currently, PT PLN Batam is in a state of electricity surplus due to reduced electricity absorption by customers.

This research is intended to evaluate the 
economic/financial feasibility of constructing a submarine cable to replace the operation of a Diesel power plant (PLTD) as one of the new business development opportunities for PT PLN Batam.

\section{LITERATURE REVIEW}

To obtain data that will be used in investment analysis, what must be obtained first is data on the costs of CAPEX and OPEX for the construction and operation of submarine cables.

CAPEX and OPEX costs are obtained by calculating costs based on bathymetry survey results and technical studies of submarine cable construction.

WACC (Weighted Average Cost of Capital)

Related to business feasibility, capital composition is an important element. This project is planned to be funded through $30 \%$ equity (equity) and $70 \%$ loan from financial institutions with a term of 7 years.

This composition will affect the value of the cost of capital or cost of capital in this feasibility calculation. In general, the cost of capital or cost of capital is the real cost that has been used by the company to obtain funding sources from debt, preferred stock, common stock or retained earnings to fund investments. In addition, this cost of capital also reflects the minimum rate of return of an investment that is worth obtaining in relation to its risk; with the aim of optimizing the value of the company and its shareholders.

The concept of cost of capital is related to long-term decisions related to fixed assets or capital budgeting issues. Calculation of the cost of capital is also related to taxes. The cost of capital is not only the cost of debt or the cost of equity but is calculated through the weighted weight of all components in the capital structure and will ultimately be used as a discount rate in the project feasibility assessment using the formula [6]:

$$
\text { WACC }=\operatorname{CoD} \frac{D}{(D+E)}+\operatorname{CoE} \frac{E}{(D+E)}
$$

Because this research focuses more on the feasibility of sea cable development, the research will focus more on investment analysis using business feasibility parameters.

The business feasibility parameters used in this study are:

1. PBP (Payback Period)

Payback period (PBP) is a certain period of time that shows the occurrence of cash inflows cumulatively equal to the amount of investment in the form of present value (Ibrahim, 2009). The payback period shows the period required to be able to cover investment expenditures using the proceeds generated from the investment. If the annual proceeds are the same, the payback from an investment can be calculated by dividing the investment amount by the annual proceeds.

2. NPV (Net Present Value)

This method takes into account the time value of money. This method calculates the present value of cash inflows and outlays of an investment using a certain interest rate. This method pays attention to the proceeds and time value of money.

3. IRR (Internal Rate of Return)
IRR is a method that already takes into account the time value of money. This method is used to determine the interest rate that will make the total present value of the proceeds expected to be received equal to the total present value of capital expenditures. By using the Goal Seek function in the Microsoft Excel application, IRR calculations become easier and faster.

4. BCR (Benefit To Cost Ratio)

$\mathrm{B} / \mathrm{C}$ Ratio is a measure of the comparison between income and total production costs. $\mathrm{B}$ means a benefit, while $\mathrm{C}$ means cost. The calculation of this $b / c$ ratio is calculated from the interest rate.

Within the limits of the amount of the $\mathrm{B} / \mathrm{C}$ value, it is used as a tool to find out whether a business is profitable or not.

\section{Methodology}

This study, which was carried out to conduct a business feasibility analysis was to use the data from the Bathymetry Survey and the results of the Technical Study that had been carried out by PT PLN Batam previously.

Below is a flow chart of the research methods carried out.

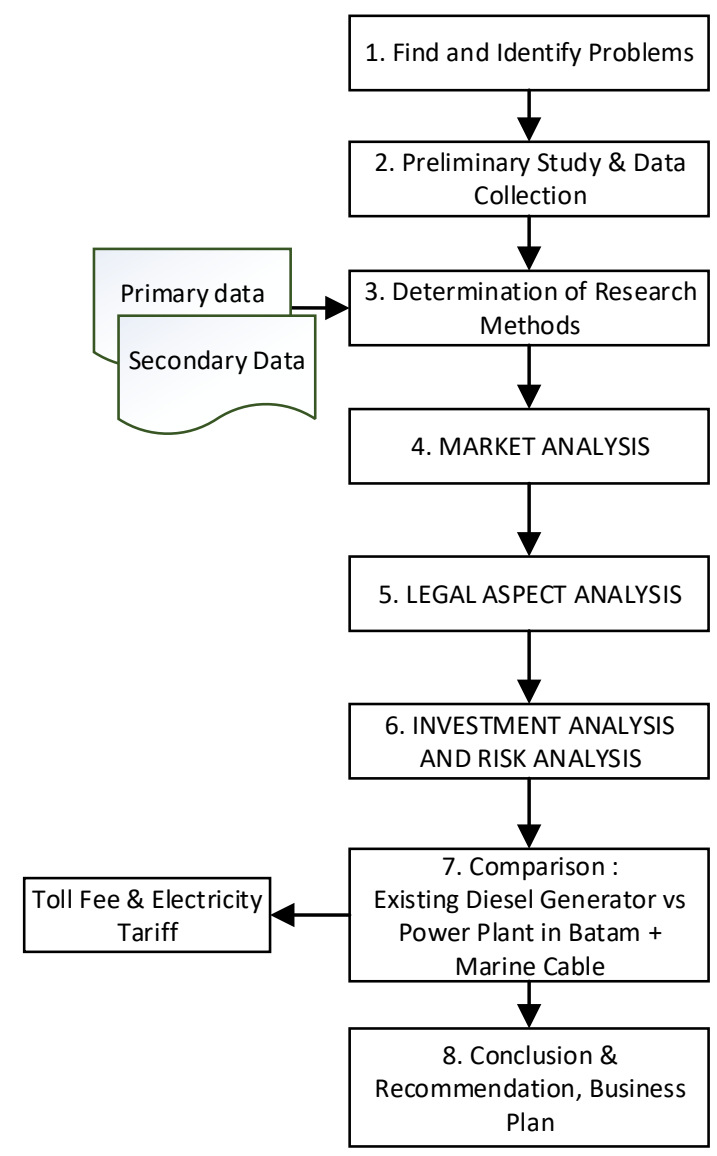

Fig. 1. Research Methods.

From the results of the Bathymetry survey, it is known that the required submarine cable length is $1,194 \mathrm{~m}$.

Below is a flow chart of the investment analysis methods carried out. 


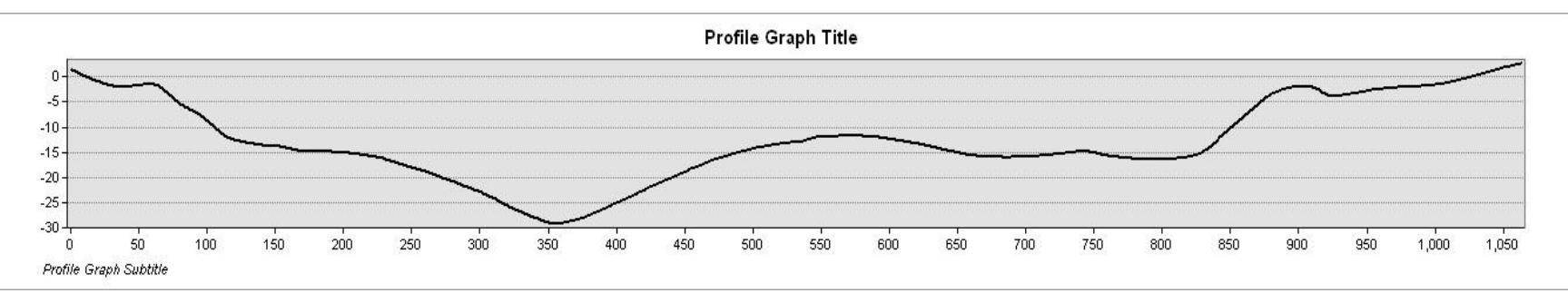

Fig. 2. Shortest Route.

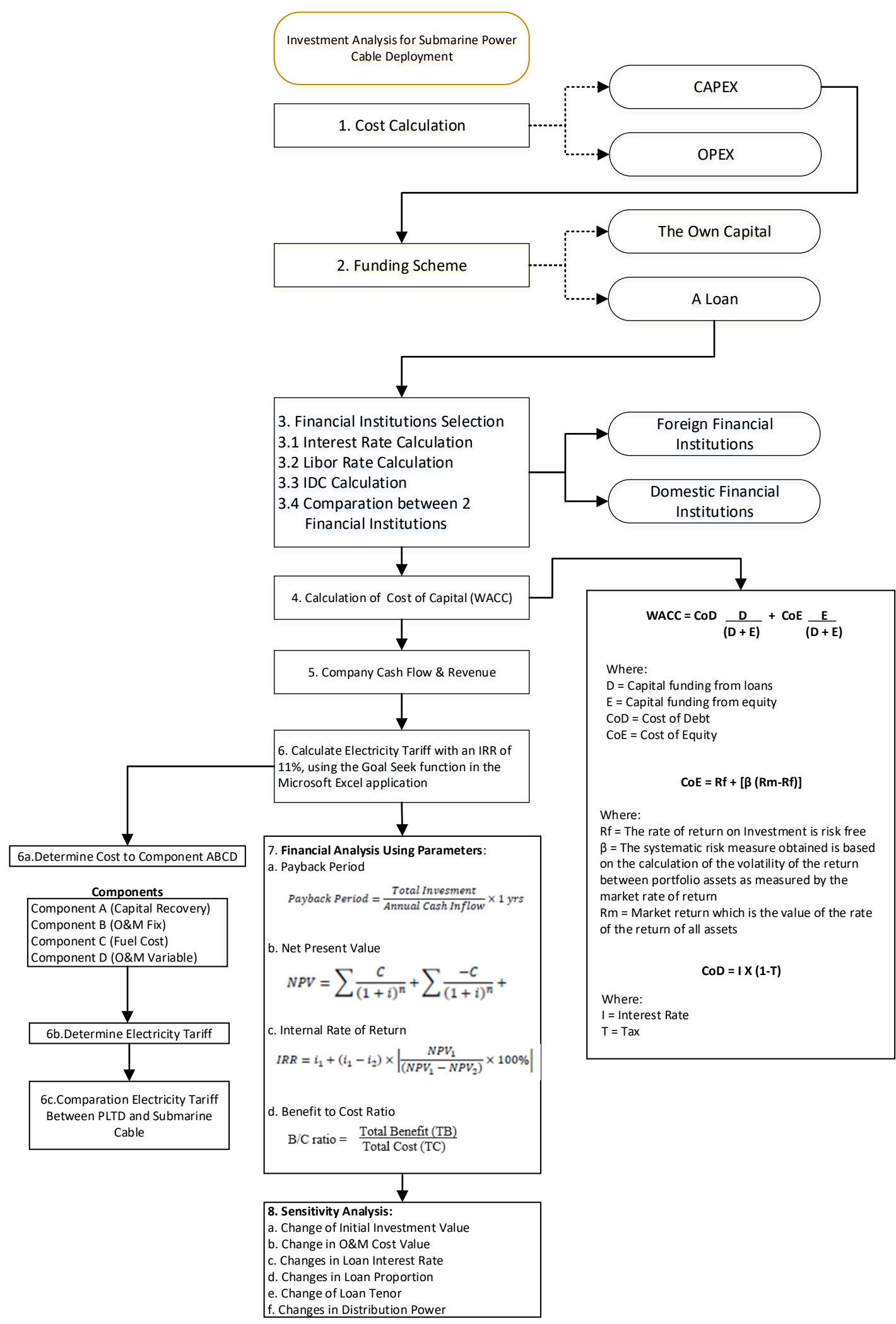

Fig. 3. Flow Chart of Investment Analysis Method. 


\section{Findings AND ARGUMENT}

The total project investment cost for this calculation is obtained from a similar study conducted by a consultant hired by PLN Batam. In estimating the Investment Cost, the reference and benchmark data used are based on reference data for similar submarine cable work projects that have the same or close to capacity. If the reference to similar marine works projects is used using data within a certain period of time, adjustments will be made to take into account inflation and/or exchange rate differences.

The calculation of investment costs includes the following scopes:

- Raw material procurement;

- Preparation work and mobilization-demobilization;

- Installation work;

- As built drawing and international map registration.

From the results of the analysis carried out, the following results are obtained:

\section{A. Cost of Capital}

\begin{tabular}{cc} 
TABLE I: COST OF CAPITAL \\
\hline Component & Value \\
\hline Monthly Return & $1.2 \%$ \\
$\%$ Debt & $70 \%$ \\
\% Equity & $30 \%$ \\
Yearly Return & $15.03 \%$ \\
Risk Free Rate 20 year & $7.4 \%$ \\
Risk Premium & $7.58 \%$ \\
Tax & $25.0 \%$ \\
Unlevered Beta & 0.52 \\
Leverage (D/E) & $233.3 \%$ \\
Levered Beta & 1.42 \\
Cost of Equity & $18.2 \%$ \\
Cost of Debt & $8.00 \%$ \\
Cost of Debt After Tax & $6.00 \%$ \\
WACC & $9.67 \%$ \\
\hline
\end{tabular}

\section{B. Initial Investment Cost (CAPEX)}

\begin{tabular}{cccccc}
\multicolumn{6}{c}{ TABLE II: CAPEX } \\
\hline No & Description & Quantity & Unit & Unit Price (Rp) & Amount (Rp) \\
\hline 1 & Material & 1 & Lot & 8.244 .316 .568 & 8.244 .316 .568 \\
2 & $\begin{array}{c}\text { Preparation } \\
\text { Work }\end{array}$ & 1 & Lot & 3.367 .893 .245 & 3.367 .893 .245 \\
& $\begin{array}{c}\text { Installation } \\
\text { Work }\end{array}$ & 1 & Lot & 13.051 .123 .102 & 13.051 .123 .102 \\
& $\begin{array}{c}\text { As Build } \\
\text { Drawing }\end{array}$ & 1 & Lot & 500.000 .000 & 500.000 .000 \\
& & Total & & & 25.163 .332 .917 \\
\hline
\end{tabular}

\section{OPEX Cost}

\begin{tabular}{cccc}
\multicolumn{4}{c}{ TABLE III: OPEX } \\
\hline No & Component & Cost (Rp) & Cost/Year (Rp) \\
\hline 1 & $\begin{array}{c}\text { Minor Maintenace } \\
\text { Scope (6 Months) } \\
\text { Major Maintenace } \\
\text { Scope (12 Months) } \\
2\end{array}$ & $200,000,000$ & $400,000,000$ \\
& $\begin{array}{c}\text { Major Maintenace } \\
\text { Scope (5 Years) } \\
3\end{array}$ & $2,000,000,000$ & $400,000,000$ \\
4 & $\begin{array}{c}\text { Employee Fees and } \\
\text { Others }\end{array}$ & $632,000,000$ & $632,000,000$ \\
5 & Variable Operating Cost & 48.482 .057 & 48.482 .057 \\
& Total & & $2,097,314,048$ \\
\hline
\end{tabular}

\section{Toll Fee Tarif}

\begin{tabular}{cc} 
TABLE IV: TOLL FEE TARIF \\
\hline Components & Value \\
\hline Component A (Capital Recovery) & 111 \\
Component B (O\&M Fix) & 42 \\
Component C (Fuel) & 0 \\
Component D (O\&M Variable) & 1 \\
Total & 154 \\
\hline
\end{tabular}

\section{E. Business Feasibility Parameters}

TABLE V: FEASIBILITY VALUE

\begin{tabular}{cc}
\multicolumn{2}{c}{ TABLE V: FEASIBILITY VALUE } \\
\hline Components & Value \\
\hline Net Present Value & $2,479,587,713$ \\
IRR & $11.02 \%$ \\
Payback Period & 7 Year 11 Month \\
Benefit Cost Ratio & 2.51 \\
\hline
\end{tabular}

\section{F. Risk Mitigation Plan}

There are 4 (four) Risk Mitigation Plans need more attention because they have a fairly high level of risk (Table VI).

TABLE VI: RISK MITIGATION

\begin{tabular}{|c|c|c|}
\hline No. & Risk & $\begin{array}{c}\text { Risk Mitigation Plan } \\
\end{array}$ \\
\hline 1 & $\begin{array}{l}\text { Construction } \\
\text { Work Delay }\end{array}$ & $\begin{array}{l}\text { 1. Preparation of a work contract by including a } \\
\text { penalty clause in the event of a delay } \\
\text { 2. Make a more detailed Work Planning to avoid the } \\
\text { risk of disputes occurring during the } \\
\text { implementation of development } \\
\text { 3. Selection of a more stringent workmanship vendor } \\
\text { by looking at the track record or performance of the } \\
\text { contractor as the main requirement for appointing } \\
\text { the winner of the auction }\end{array}$ \\
\hline 2 & $\begin{array}{l}\text { Decrease in } \\
\text { the amount } \\
\text { of electricity } \\
\text { demand }\end{array}$ & $\begin{array}{l}\text { 1. Preparation of long-term contracts with a minimum } \\
\text { purchase of electricity and fluctuating toll fee rates } \\
\text { in accordance with the distribution power range. } \\
\text { 2. If the minimum amount of electricity distributed to } \\
\text { the channel decreases to } 6.862 \mathrm{MWh} \text { per year at a } \\
\text { tariff, then the toll fee rate is Rp. } 1.100 / \mathrm{Kwh} \text {. } \\
\text { 3. If the electricity demand is less than } 6.862 \mathrm{MWh} \\
\text { per year, then the toll fee tariff amendment must be } \\
\text { carried out by re-activating the Business Feasibility } \\
\text { Analysis. } \\
\text { 4. Toll fee rates will apply normally even though there } \\
\text { is a decrease in distribution power of }-3 \% \text { or } 1,471\end{array}$ \\
\hline 3 & $\begin{array}{l}\text { Risk of State } \\
\text { Loss }\end{array}$ & $\begin{array}{l}\text { Preparation of long-term contracts in accordance with } \\
\text { the age of the project with clear legal consequences if } \\
\text { there is a change in the mechanism of cooperation } \\
\text { between parties during the project. }\end{array}$ \\
\hline 4 & $\begin{array}{l}\text { PJBTL risk } \\
\text { ends } \\
\text { prematurely }\end{array}$ & $\begin{array}{l}\text { Preparation of long-term contracts according to the } \\
\text { age of the project with a statement of commitment } \\
\text { from Pertamina regarding the minimum purchase of } \\
\text { electricity with the amount and length of the period in } \\
\text { accordance with the age of the project that was agreed } \\
\text { at the beginning. } \\
\text { In the event that PJBTL ends prematurely, the party } \\
\text { who terminates the contract must provide } \\
\text { compensation for the amount agreed in the contract. }\end{array}$ \\
\hline
\end{tabular}

It is necessary to calculate the effect of decreasing electricity power on toll fees and electricity tariffs as described in the graph below. 


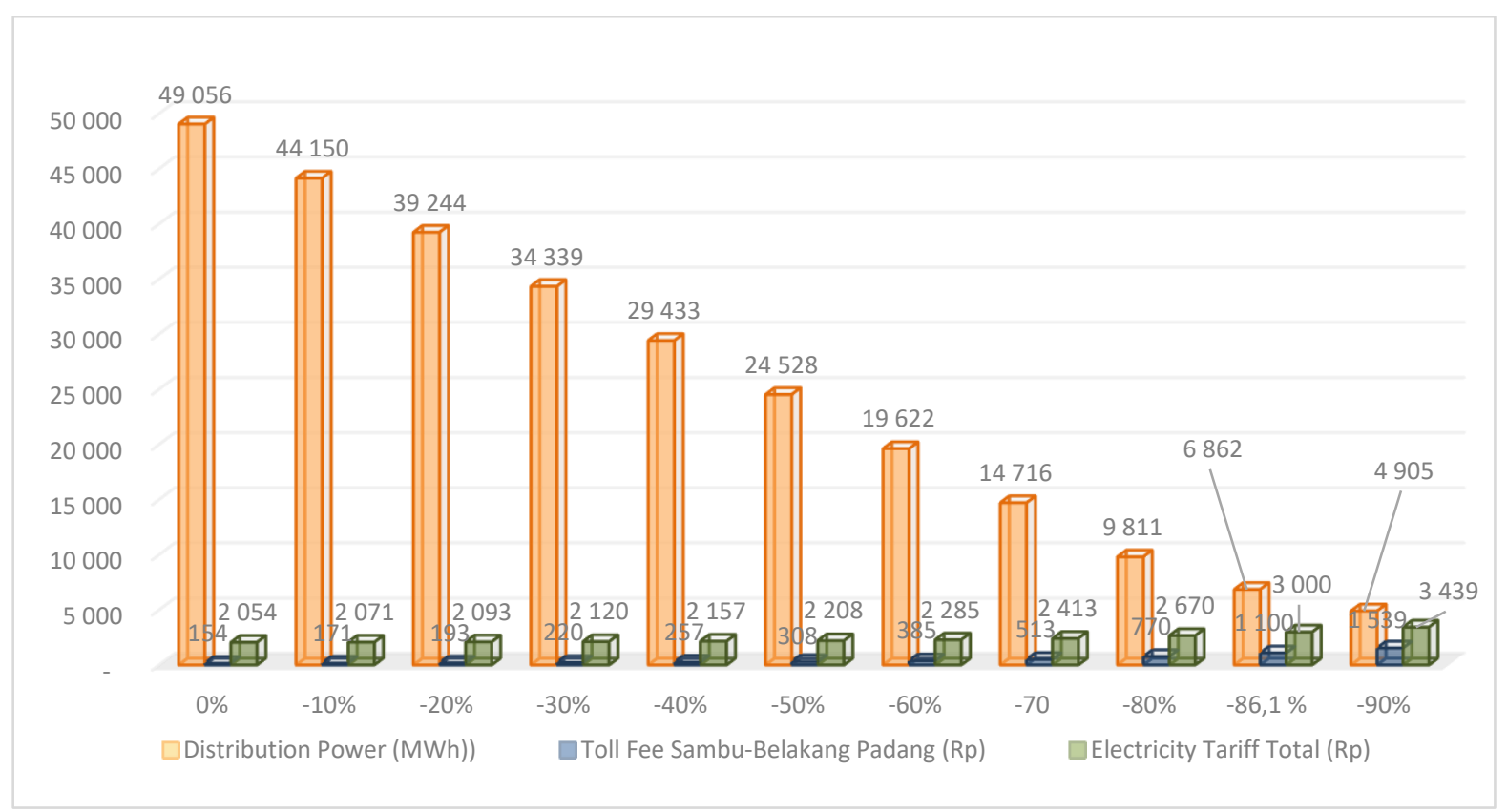

Fig. 4. The Effect of Decreasing Electricity Power on Toll Fees and Electricity Tariffs.

The data presented in the graphs above are useful for management in making decisions when discussing electricity rates and toll fees with PT PLN WRKR, where electricity rates are made progressive depending on the electrical power supplied to the submarine cable line.

\section{CONCLUSIONS}

The conclusions obtained from this research are as follows:

1. From the results of the technical study, the plan to deploy a $20 \mathrm{KV}$ medium-voltage submarine cable line from Belakang Padang to Pulau Sambu can be continued for the construction phase.

2. The results of the investment analysis state that the capital is obtained by using $30 \%$ equity and $70 \%$ loans from domestic financial institutions with a loan period of 7 years

3. From the results of the Economic Study, the electricity tariff using this submarine cable channel is Rp. 2.054/Kwh with a toll fee rate of Rp. 154/Kwh.

4. With an electricity tariff of Rp. $2.054 / \mathrm{Kwh}$, then it can be stated from the point of view of economic studies:

\begin{tabular}{cccc}
\multicolumn{4}{c}{ TABLE VII: FEASIBILITY RESULT } \\
\hline Components & Value & Remarks & Status \\
\hline Net Present Value & $2,479,587,713$ & $>0$ & Feasible \\
IRR & $11.02 \%$ & $>$ WACC & Feasible \\
Payback Period & 7 Year 11 & $\leq$ Asset & Feasible \\
Benefit Cost Ratio & Month & live & \\
\hline
\end{tabular}

5. The payback period for the medium-voltage submarine cable line construction project from Belakang Padang to Pulau Sambu is 7 years and 11 months.

6. The electricity tariff using this submarine cable line (Rp. $2,054 / \mathrm{Kwh})$ is cheaper than the electricity tariff using PLTD (Rp. 3,000/Kwh).

7. By using medium-voltage submarine cables to distribute electricity from Batam to Sambu Island, the company gets a double benefit, namely : a. The operating profit of the power plant in Batam is $16 \%$ from BPP Batam.

b. Advantages of imposing a toll fee for the use of medium-voltage submarine cable lines from Belakang Padang -Sambu Island.

8. With electricity tariffs equal to PLTD rates (Rp. $3,000 / \mathrm{Kwh}$ ), if there is a decrease in electricity distribution capacity, the minimum power supplied is 6.862 MWh per year. The normal power capacity that should be distributed by this submarine cable line is 49.056 MWh per year.

9. If the power supplied turns out to be less than the minimum power, a contract review must be carried out with PT PLN WRKR to negotiate the toll fee rate.

10. In order to minimize risk, it is important for management to pay attention to the steps contained in risk mitigation plan.

11. The potential profit from the operation of a mediumvoltage submarine cable with a tariff of Rp. $2,054 / \mathrm{Kwh}$ is:

a. Potential profit of the Batam Power Plant: $16 \% \times \mathrm{Rp}$ $1.341,60 / \mathrm{Kwh} \times 7.000 \mathrm{Kwh} \times 24$ hour $\times 365$ days $\times 0.8$ $=\operatorname{Rp} 10.530 .164 .736 /$ year.

b. Potential benefits of Toll Fee Tariff for using submarine cable line $=$ IDR Rp1.828.395.737 in the first year.

c. So, the total potential profit obtained is Rp. 10.530.164.736 + $\mathrm{Rp} 1.828 .395 .737=\mathrm{Rp}$ 12.358 .560 .473 ,- in the first year.

\section{RECOMMENDATION}

By looking at the results of this project analysis, it can be recommended to be able to immediately carry out the construction of a submarine cable segment from Belakang Padang island to Sambu island, in order to provide benefits for all parties involved. 


\section{REFERENCES}

[1] F. E. Brigham, F. J. Houston, Dasar-Dasar Manajemen Keuangan. Terjemahan Buku Dua. Jakarta: Salemba Empat; 2011.

[2] A. Damodaran, Applied Corporate Finance. 3rd Edition. United State: Wiley; 2011

[3] Dr. Kasmir SE. MM., Studi Kelayakan Usaha. Jakfar SE. MM..Jakarta: Kencana Prenada Media Group, ISBN 978-602-9413-09-0 650.; 2013.

[4] Ibrahim Yacob. Studi Kelayakan Bisnis. Edisi Revisi. Jakarta: Rineka Cipta; 2009.

[5] F. B. Eygene. Financial Management Theory and Practice. 10th Edition. United State: Thomson; 2002.

[6] J. L. Gitman, Principles of Managerial Finance. 13th Edition. United States: Pearson Education Inc.; 2012.

[7] Todd Jick, Risk Management and Financial Institutions. 4th Edition. McGraw-Hill; 2011.

[8] Van Deventer. Advanced Financial Risk Management. Donald R. John. Wiley \& Sons; 2005.

[9] Eric Verzuh. Portable MBA in Project Management. John Wiley \& Sons, Inc,; 2003.

[10] David I. Cleland, Project Management: Strategic Design and Implementation. 5th Edition. Ireland, Lewis R. London: McGraw-Hill; 2006.

[11] PT PLN Batam. Annual report PT PLN Batam. Batam: PLN Batam; 2020.

[12] PT PLN Batam. Laporan Pengusahaan PT PLN Batam. Batam: PLN Batam; 2021.

[13] PT. PLN Batam. Pembuatan Harga Perkiraan Engineering (HPE) Pembangunan Jalur Kabel Laut Tegangan Menengah 20 KV P Batam - P Buluh. Batam: PLN Batam; 2017.

[14] PT PLN Batam. Pengadaan Sewa PLTD 4 x 1 MW di Mukomuko Bengkulu antara PT PLN Batam dengan KSO PT Beringin Mas Powerindo dan PT VPower Operation Services. Batam: PLN Batam; 2019.

[15] PT PLN Batam, RKAP PT PLN Batam. Batam: PLN Batam; 2021.

[16] PT. PLN Batam. Studi Kelayakan Penyediaan Layanan Khusus Pertamina Ep Asset 1 Lirik Field. Batam: PLN Batam; 2021.

[17] PT PLN Batam. Studi Teknis Kabel Laut 20 KV Pulau Belakang Padang - Pulau Sambu. Batam: PLN Batam; 2021.

[18] Pertamina. (2021, July $7^{\text {th }}$ ) Daftar Harga [online]. Available: https://www.pertamina.com/id/news-room/announcement/.

[19] Macro Trends.(nd). (2021, August $12^{\text {th }}$ ). LIBOR Rates [online]. Available: https://www.macrotrends.net/1433/historical-libor-rateschart,; 2021.

[20] Aerial Photograph Studio. (nd). (2021, May $20^{\text {th }}$ ). Jasa Pemetaan dasar sungai danau laut bathymetric [online]. Available: https://www.jasapemetaan.com/2016/11/jasa-pemetaan-dasar-sungaidanau-laut.html; 2021.

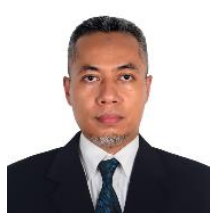

Agus Wibowo, since 2003 until now has a career at PT PLN Batam - Indonesia, and his current position is in the Strategic Procurement Division. He is currently pursuing his master's degree in Business Administration from the Institute of Technology Bandung.

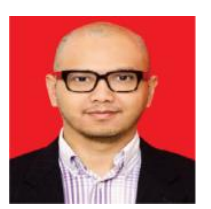

Erman Sumirat is currently a lecturer at the School of Business and Management Institute of Technology Bandung (SBM ITB). He received a MBuss in Finance from Monash University. Erman is also a Certified Securities Analyst (CSA) and Certified Risk Professional (CRP) holder.

Research areas that he focuses on include Islamic Banking, Islamic Finance, Corporate Finance, Business Risk Management, and Economics. In addition, the teaching area he has mastered includes Corporate Finance, Business Risk and Capital Market, Business Economics, Financial Management. 